Marcin Böhm (Opole)

\title{
NikePhoros BryenNios THE YOUNGER - the First One Not to Become a Blind Man? Political and Military History of the Bryennios FAMILY IN THE $11^{\text {Th }}$ AND EARLy $12^{\text {TH }}$ CENTURY
}

$\mathrm{N}$ ikephoros Bryennios the Younger (1062-1137) has a place in the history of the Byzantine Empire as a historian and husband of Anna Komnene (1083-1153), a woman from the imperial family. His historical work on the history of the Komnenian dynasty in the $11^{\text {th }}$ century is an extremely valuable source of information about the policies of the empire's major families, whose main goal was to seize power in Constantinople ${ }^{1}$. Nikephoros was also a talented commander, which he proved by serving his father-in-law Alexios I Komnenos (1081-1118) and brother-in-law John II Komnenos (1118-1143). The marriage gave him free access to people and documents which he also enriched with the history of his own family. It happened because Nikephoros Bryennios was not the first representative of his family who played an important role in the internal policy of the empire. He had two predecessors, his grandfather, and great grandfather, who according to the family tradition had the same name as our hero. They

\footnotetext{
${ }^{1}$ J. SEGER, Byzantinische Historiker des zehnten und elften Jahrhunderts, vol. I, Nikephoros Bryennios, München 1888, p. 31-33; W. Treadgold, The Middle Byzantine Historians, Basingstoke 2013, p. 344-345; A. Kazhdan, Bryennios, Nikephoros the Younger, [in:] ODB, vol. I, p. 331; L. Neville, A History of the Caesar John Doukas in Nikephoros Bryennios' Material for History?, BMGS 32, 2008, p. 168-169; EADEM, Heroes and Romans in Twelfth-Century Byzantium. The Material for History of Nikephoros Bryennios, Cambridge-New York 2012, p. 15-16; V. STAnković, Nikephoros Bryennios, Anna Komnene and Konstantios Doukas. A Story about Different Perspectives, BZ 100, 2007, p. 169-175; E. JefFreys, Nikephoros Bryennios Reconsidered, [in:] The Empire in Crisis(?). Byzantium in the $11^{\text {th }}$ Century, (1025-1081), ed. V.N. Vlyssidou, Athens 2003, p. 211-213; J. Howard-Johnston, Anna Komnene and the Alexiad, [in:] Alexios I Komnenos, ed. M. Mullett, D. Smythe, Belfast 1996, p. 232-302; R. MACrides, The Pen and the Sword: Who Wrote the Alexiad?, [in:] Anna

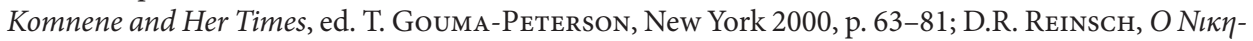

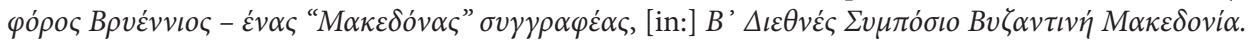

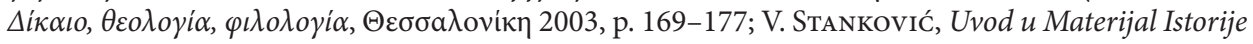
Nićifora Vrijenija, ЗРВИ 47, 2010, p. 137-148.
} 
both took part in usurpations against the reigning emperors, for which they were blinded. Therefore, in this article we will try to determine why the fate of our hero was not similar.

The Bryennios family appears in Byzantine sources for the first time in one of the works of Constantine Porphyrogenetus (913-959), De administrando imperio ${ }^{2}$. Its first known representative is a protospatharios Theoktistos Bryennios. This man was the strategos of the Peloponnese theme during the reign of Theophilos (829-842). His main task was to break up the Slav rebellion, which he accomplished brilliantly, subjecting to the imperial power some of their tribes, while he pushed two tribes (Ezeritai and Melingoi) into the mountains and imposed tribute on them ${ }^{3}$. Constantine Porphyrogenitus mentions in the above account that Theoktistos commanded an army of Thracians, Macedonians and people from other Western provinces ${ }^{4}$. This indicates that our hero's family came from the Balkan part of the empire and its roots should be sought there. Unfortunately, we do not know whether he may be the direct ancestor of Bryennios from the $11^{\text {th }}$ century ${ }^{5}$.

Another representative of the Bryennios family directly related to our hero is his great grandfather of the same name. Nikephoros Bryennios, whom we will describe as the first (I) in this article, came from Adrianople, which indicates that his family remained there since the ninth century as one of the most important families ${ }^{6}$. According to Skylitzes, around 1050 during the Patzinkas invasion, this patrician Nikephoros (I) was appointed by the emperor Constantine IX Monomachos (1042-1055) as the ethnarch who commanded troops consisting of Varangians, Franks and Turkmen horse archers ${ }^{7}$. Adrianople, Macedonia, and Thrace became the field of military operations conducted by Nikephoros Bryennios (ethnarch), where he defeated the opponents from the Black Sea Steppe. In his actions he cooperated with patrician Michael the akolouthos who commanded a formation of the Varangians. Their cooperation led to victories at Goloes, Toplitzos, and, finally,

\footnotetext{
${ }^{2}$ Constantine Porphyrogenitus, De administrando imperio, 50, ed. G. Moravcsik, trans. R.J.H. JenKins, Washington 1993 [= CFHB, 1; DOT, 1] (cetera: Constantine Porphyrogenitus), p. 232.

${ }^{3}$ Constantine Porphyrogenitus, 50, p. 232; A. Kazhdan, Bryennios, [in:] ODB, vol. I, p. 328 329; F. CurTa, The Edinburgh History of the Greeks, c. 500 to 1050. The Early Middle Ages, Edinburgh 2011, p. 135-140; Theoktistos Bryennios, [in:] PMZ, Abt. I, (641-867), vol. IV, Platon - Theophylaktos, ed. F. Winkelmann, R.-J. LiLie, Berlin 2001, p. 581-582, nr 8052; S. Rajković, Porodica Vrijenija u XI i XII stoleću, Belgrade 2003, p. 32-33.

${ }^{4}$ Constantine Porphyrogenitus, 50, p. 232.

${ }^{5}$ A. Kazhdan, Bryennios..., p. 329.

${ }^{6}$ Ibidem.

${ }^{7}$ Ioannis Scylitzae Synopsis historiarum, rec. I. Thurn, Berolini 1973 [= CFHB, 5] (cetera: SkYLITZES), p. 471; S. WitteK-DE Jong, Le césar Nicéphore Bryennios, l'historien, et ses ascendantes, B 23, 1953, p. 467; S. Rajković, Porodica..., p. 40-41.
} 
Charioupolis where they slaughtered Patzinkas and stopped their raids on the Balkans for several years ${ }^{8}$. This success influenced the further career of the ethnarch.

According to the account of the irreplaceable Skyliztes, Nikephoros Bryennios (I), at the end of the life of the emperor Constantine Monomachos was one of the commanders leading troops of Macedonians operating in the east of the empire. While there, he received information about the death of this ruler and a change on the throne in Constantinople?. The ethnarch disagreed with the policy of the new ruler, Theodora, so he abandoned the front on which he operated and headed to Chrysopolis. In that city he was captured by the empress who sentenced him to exile and the confiscation of his property ${ }^{10}$ for desertion from his position. After Theodora's death, he asked her successor Michael VI (1056-1057), who brought him back to his position, to return the money she had taken from him, but he was refused and was humiliated by the new emperor ${ }^{11}$. This was one of the reasons for the conflict between Bryennios (I) and the emperor, which was soon to escalate.

Bryennios was later sent to fight against the Turks and their leader Samouch. This expedition coincided with the preparations for rebellion against the emperor, formed in the ranks of army commanders from the east ${ }^{12}$. Skylitzes mentions that one of their leaders, Kekaumenos, opted to include Bryennios in the plot because he headed the army of Macedonians ${ }^{13}$. Ethnarch Bryennios travelled east with patrician John Opsaras who carried money for the army. When they arrived at a place deep in Anatolia, they began to distribute money to troops from Cappadocia. When Bryennios ordered the sums intended for soldiers to be increased, Opsaras opposed him, arguing there were no proper orders from the emperor. This led to the rage of the ethnarch who beat Opsaras, ordered him to be shackled and kept under guard in his tent ${ }^{14}$. Then he distributed imperial money according to his preferences. Lykanthes, the commander of Pisidia and Lycaonia, who was

\footnotetext{
${ }^{8}$ Skylitzes, p. 472-473; A. Paroń, Pieczyngowie. Koczownicy w krajobrazie politycznym i kulturowym średniowiecznej Europy, Wrocław 2015, p. 388-389; J. BonareK, Bizancjum w dobie bitwy pod Mantzikert. Znaczenie zagrożenia seldżuckiego w polityce bizantyńskiej w XI wieku, Kraków 2011 [= N.SAB, 7], p. 84-85; P. STEPhenson, Byzantium's Balkan Frontier. A Political Study of the Northern Balkans, 900-1204, Cambridge 2000, p. 94.

${ }^{9}$ Skylitzes, p. 479.

${ }^{10}$ Skylitzes, p. 480; J. BonareK, Bizancjum..., p. 46; B. Krsmanović, Uspon vojnog plemstva u Vizantii XI veka, Beograd 2001, p. 142-144; J. Dudek, Pęknięte zwierciadło. Kryzys i odbudowa wizerunku władcy bizantyńskiego od 1056 do ok. 1095 roku, Zielona Góra 2009, p. 50; S. RAJKović, Porodica..., p. 41-42.

${ }^{11}$ Skylitzes, p. 484.

${ }^{12}$ M. Böнm, The Military Policy of Isaac Komnenos at the Time of Battle of Petroe (1057), OPS 1, 2018, p. 137-139.

${ }^{13}$ Skylitzes, p. 487; S. Rajković, Porodica..., p. 46.

${ }^{14}$ Skylitzes, p. 487-488.
} 
encamped nearby, attacked the Bryennios camp after receiving the news of the ethnarch's actions. Also Lykanthes surprised Bryennios with his actions. Perhaps he had an advantage over his forces because he had two units from Anatolia under his command. Bryennios was captured and Opsaras was freed. The latter personally blinded Nikephoros Bryennios (ethnarch) for the rebellion against the imperial power and then sent him back to the emperor ${ }^{15}$.

Ethnarch Nikephoros Bryennios left behind two sons, Nikephoros Bryennios the Elder (II) and John ${ }^{16}$. The second Nikephoros, like his father, was looking for a way of life for himself, starting his career in the empire's army. Anna Komnena mentions that the emperor Roman Diogenes (1020-1072) made Nikephoros (II) his brother through adoption ${ }^{17}$. This was probably at the very beginning of the reign of this basileus. Bryennios soon proved his worth as a commander. He took part in the campaign against Seljuks, which ended in defeat at Mantzikert ${ }^{18}$. He was one of the few commanders who discouraged the emperor from starting an open battle, suggesting that it would be better for the Byzantines to strengthen themselves in nearby cities, burn the nearby fields to starve the enemy, and finally wait in Theodosioupolis ${ }^{19}$. Before the battle, Roman IV entrusted Bryennios with the order of banishing the army of Turkish marauders. However, it turned out that the Turks put up fierce resistance, and the troops commanded by Nikephoros proved to be too small to meet this task, which is why he asked for the support of the emperor who did not understand the situation and accused him of cowardice $^{20}$. Roman eventually sent him as support the unit of Nikephoros Basilakes which, however, chased after the Turks who pretended to escape, falling in a booby

\footnotetext{
${ }^{15}$ Skylitzes, p. 488; K. Inoue, The Rebellion of Isaakios Komnenos and the Provincial Aristocratic Oikoi, Bsl 54, 1993, p. 272-273; J. Bonarek, Bizancjum..., p. 47; B. KrsmanoviĆ, Uspon vojnog..., p. 187-188; J. Dudek, Pęknięte zwierciadło..., p. 50; S. Wittek-De Jong, Le césar Nicéphore..., p. 467; S. Rajković, Porodica..., p. 47-48.

${ }^{16}$ A. Kazhdan, Bryennios..., p. 329.

${ }^{17}$ Annae Comnenae Alexias, X, 3, vol. I, rec. D.R. Reinsch, A. Kambylis, Berlin 2001 [= CFHB.SBe, 40] (cetera: Komnene), p. 288.30-35.

${ }^{18}$ E. De Vries-Van Der Velden, Psellos, Romain IV Diogenes et Mantzikert, Bsl 58, 1997, p. 274 310; S. Rajković, Porodica..., p. 52-57.

${ }^{19}$ Nicéphore Bryennios, Histoire, I, 13, rec. P. Gautier, Bruxelles 1975 [= CFHB, 9] (cetera: Bryennios), p. 107; J. BonareK, Bizancjum..., p. 161; B. Skoulatos, Les personnages byzantins de l'Alexiade. Analyse prosopographique et synthèse, Louvain-la-Neuve 1980, p. 219; J. Dudek, Pęknięte zwierciadło..., p. 197.

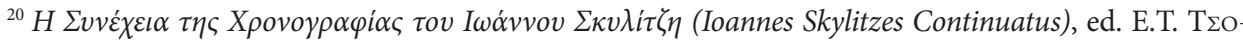

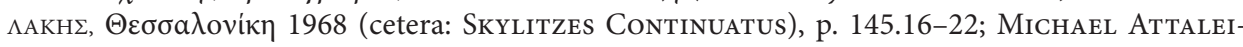
ates, The History, XX, 15, ed. A. Kaldellis, D. Krallis, Cambridge Mass. 2012 [= DOML] (cetera: Michael Attaleiates), p. 280; Ioannis Zonarae Epitome historiarum libri XIII-XVIII, XVIII, 13, 12-13, rec. T. Büttner-Wobst, Bonnae 1897 [= CSHB, 49] (cetera: Zonaras), p. 697; J. BonareK, Bizancjum..., p. 167.
} 
trap which Bryennios did not fall for. Along with its leader, the unit that came with Basilakes got captured by Seljuks ${ }^{21}$. Communication between the Byzantines failed here. Bryennios who, according to his grandson, was in command at the left wing of the army, tried to come to the rescue of his companion at the behest of the emperor, but this proved impossible ${ }^{22}$. Our hero's attempt to come to the rescue was successful. Despite the wound he managed to prevent the Turks from flanking his unit and successfully return to the camp ${ }^{23}$. With a wound and subsequent injuries, he continued to command the left wing, and was so successful that he managed to lead most of his people out of the defeat at Mantzikert ${ }^{24}$. This highly subjective vision presented by Nikephoros of his grandfather's bravery at the end of the battle of Mantzikert, is not entirely consistent with the accounts of other sources. Michael Attaliates does not say a word about Bryennios's actions in the final phase of the battle, especially after the capture of Emperor Roman IV. Skylitzes Continuatus similarly does not mention any greater activity of this representative of the Bryennios family in the end of that battle lost by the Byzantines.

Despite the defeat of his adoptive brother in the battle and later in the civil war, Bryennios (II) did not end up like him. The Emperor Michael VII Doukas (10711078) in 1075 summoned him from Odrysoi (Thrace) to Constantinople. There, he was elevated to the position of the doux of Bulgaria and was also entrusted with the task of breaking up the Slavic uprising in this land, a task which he successfully completed ${ }^{25}$. Recognising his military skills, the emperor later transferred him to the position of the doux of Dyrrachion, with the order of fighting against the Normans of southern Italy, Croats and the inhabitants of Duklja ${ }^{26}$. In the Western Balkans Bryennios effectively began his operations by fighting on land with the Slavs. He was successfully using local people as guides while clearing roads through passes manned by Croats and Dukljans, which enabled him to smash them in battle, capture their cities and take hostages from them, as a guarantee of their loyalty to the empire ${ }^{27}$. He also managed to rebuild the provincial fleet of Dyrrachion to some extent, which he used to fight the pirates from Italy who hunted merchant ships heading for the port-capital of the province he $\operatorname{led}^{28}$.

\footnotetext{
${ }^{21}$ Skylitzes Continuatus, p. 146.3-8; Zonaras, XVIII, 13, 15-16, p. 698; Michael Attaleiates, XX, 16, p. 282; J. BonareK, Bizancjum..., p. 168-169.

${ }^{22}$ Bryennios, I, 14, p. 107-109.

${ }^{23}$ BryenNios, I, 15, p. 111-113.

${ }^{24}$ Bryennios, I, 16, p. 115; J. Bonarek, Bizancjum..., p. 170-171.

${ }^{25}$ Bryennios, III, 2-3, p. 211-213; S. Rajković, Porodica..., p. 59.

${ }^{26}$ Bryennios, III, 3, p. 213; S. Wittek-DE Jong, Le césar Nicéphore..., p. 465; B. Skoulatos, Les personnages..., p. 220; L. Neville, Heroes..., p. 121; S. Rajković, Porodica..., p. 60.

${ }^{27}$ Bryennios, III, 3, p. 213-215.

${ }^{28}$ Bryennios, III, 3, p. 215.
} 
The wining streak was interrupted by a change in the imperial policy towards the Seljuks, including concessions giving them almost all Anatolia, with which Bryennios disagreed. In 1077 he was dismissed from his position for his views, which led him on a straight path to rebellion. He proclaimed himself emperor and headed for his family Adrianopol leading his faithful troops ${ }^{29}$. The route he chose ran through Thessaloniki, where he met with Basilakes who was sent to replace him as the doux of Dyrrachium, and who did not defeat the new usurper ${ }^{30}$. Then he headed for Traianoupolis, where his brother John was waiting for him, along with the Varangians and Frankish troops, to which many Macedonians joined ${ }^{31}$. In Traianoupolis, he was proclaimed as the emperor, thus challenging the power of Michael VII ${ }^{32}$. Bryennios (II) according to his grandson considered rebellion as a terrible thing that would cause great evil ${ }^{33}$. People from the cities of Raidestos and Panion joined the usurpation ${ }^{34}$. In the first of these cities he made his brother John a kouropalates ${ }^{35}$. John was then sent at the head of the army towards Constantinople with an order to seize the city because Bryennios (II) hoped that the opposition against Michael VII would help him seize it ${ }^{36}$. The attempt was a failure and John achieved nothing ${ }^{37}$. Besides, the battle of Athyra in the suburbs of Constantinople, lost by Bryennios, did not help reach an agreement with the emperor from the Doukas family ${ }^{38}$.

Nikephoros Bryennios the Elder after the failure of his brother's action finally headed to his hometown of Adrianople ${ }^{39}$. His actions coincided with the rebellion of the second usurper, Nikephoros III Botaneiates (1078-1081), whom Bryennios's earlier defeat at the capital's walls helped to seize power in the capital and the empire. Also, Bryennios had to repel Patzinkas' and Cumans' attacks on

\footnotetext{
${ }^{29}$ Skylitzes Continuatus, p. 172-173; Zonaras, XVIII, 17, 19, p. 716; Michael Attaleiates, XXXI, 1, p. 432; Michaelis Glycae Annales, rec. I. BEKKER, Bonnae 1836 [= CSHB, 24] (cetera: MIChael Glycas), p. 615-616; Komnene, I, 4, 2, p. 18; Bryennios, III, 3, p. 215-217.

${ }^{30}$ Michael Attaleiates, XXXI, 4, p. 448; Bryennios, III, 8, p. 225.

${ }^{31}$ Skylitzes Continuatus, p. 173-174; Zonaras, XVIII, 17, 20, p. 716; Michael Attaleiates, XXXI, 5, p. 450; BRYENNIOS, III, 4-5, p. 217-219.

${ }^{32}$ Michael Attaleiates, XXXI, 5, p. 450; Bryennios, III, 10, p. 231; B. Skoulatos, Les personnages..., p. 221; S. Rajković, Porodica..., p. 71-72.

${ }^{33}$ BRYENNIOS, III, 5, p. 219.

${ }^{34}$ Skylitzes Continuatus, p. 174; Zonaras, XVIII, 17, 22-23, p. 716; Michael Attaleiates, XXXI, 8, p. 454.

${ }^{35}$ Skylitzes Continuatus, p. 174.16-19; Zonaras, XVIII, 17, 23-24, p. 716; Michael Attaleiates, XXXI, 9, p. 454; L. Neville, Heroes..., p. 105.

${ }^{36}$ Skylitzes Continuatus, p. 174; Zonaras, XVIII, 17, 23-24, p. 716; Michael Attaleiates, XXXI, 9, p. 454; Bryennios, III, 10, p. 231; J. BonareK, Bizancjum..., p. 192.

${ }^{37}$ Zonaras, XVIII, 17, 25-26, p. 716; Bryennios, III, 10, p. 231; Michael Attaleiates, XXXI, 10 , p. 458; J. Dudek, Pęknięte zwierciadło..., p. 67-71.

${ }^{38}$ Michael Attaleiates, XXXI, 11-12, p. 460-464; S. Rajković, Porodica..., p. 75.

${ }^{39}$ Bryennios, III, 10, p. 231.
} 
Adrianople, which ravaged the lands around this city and threatened him direct$1 y^{40}$. Botaneiates sent his envoys three times and offered him the rank of kaisar as well as adoption, but Nikephoros rejected all the opportunities to get along with the new emperor ${ }^{41}$. In the meantime, Bryennios agreed with Patzinkas whose army was beaten by his brother, and he included them in his forces ${ }^{42}$. Later, with their help, he tried to cut Constantinople ashore from Thrace, but this plan failed ${ }^{43}$. Afterwards Bryennios marched at the head of his army toward Constantinople. He did not know that the emperor entrusted the command of the army he had gathered to Alexios Komnenos, with the title of the great domestic of the West, together with the troops of Turkish mercenaries ${ }^{44}$.

The battle took place near Kalavrye on the way to the capital, where young Komnenos blocked the armies of Bryennios ${ }^{45}$. Having a more experienced army, Bryennios was counting on victory over Komnenos troops. Among the commanders accompanying him was his brother John, and Katakalon Tarchaneiotes, who commanded the wings of the army, while the usurper headed the nobility of Thrace and Macedonia, and the best Thessalian cavalry. At the crucial moment of the battle, Patzinkas, his allies, betrayed his cause and attacked the Macedonians' camp, leading his army to collapse ${ }^{46}$. Additionally, the troops of Alexios Komnenos led Bryennios's faithful military units into a trap, which ended in a total defeat of his army ${ }^{47}$. The usurper himself, after an attempt to cross the road through the Komnenos men chasing him, was captured and transferred to Alexios ${ }^{48}$.

Komnenos handed the captured usurper to the emperor and Botaneiates blinded him, which ended his efforts to obtain the imperial $\mathrm{crown}^{49}$. Botaneiates

${ }^{40}$ Zonaras, XVIII, 18, 1, p. 716; Skylitzes Continuatus, p. 175, 184.2-5; Bryennios, III, 10, p. 231; Michael Attaleiates, XXXII, 6, p. 476-478.

${ }^{41}$ Michael Glycas, p. 616; Zonaras, XVIII, 19, 2-4, p. 721; Bryennios, IV, 4, p. 265; Skylitzes Continuatus, p. 179; Michael Attaleiates, XXXIV, 1, p. 518.

${ }^{42}$ BryenNios, III, 14, p. 237.

${ }^{43}$ Michael Attaleiates, XXXII, 14, p. 488; Skylitzes Continuatus, p. 175-176.

${ }^{44}$ Komnene, I, 4, 1, p. 18; Michael Glycas, p. 616; Zonaras, XVIII, 19, 5, p. 721; Skylitzes Continuatus, p. 180; V. Stanković, Komnini u Carigradu (1057-1185). Evolucija jedne vladarske porodice, Belgrade 2006, p. 32; S. Rajković, Porodica..., p. 83.

${ }^{45}$ Zonaras, XVIII, 19, 6, p. 721; Komnene, I, 5, 2, p. 20.

${ }^{46}$ Michael Attaleiates, XXXIV, 5, p. 528; Bryennios, IV, 6, p. 269; Komnene, I, 5, 2-3, p. 20-21; B. Skoulatos, Les personnages..., p. 221-222.

${ }^{47}$ Michael Attaleiates, XXXiV, 6, p. 530; Komnene, I, 5, 4-8, p. 21-23; J. Birkenmeier, The Development of the Komnenian Army, 1081-1180, Leiden 2002, p. 59; J. Haldon, The Byzantine Wars. Battles and Campaigns of the Byzantine Era, Stroud 2001, p. 129; N. ToBias, The Tactics and Strategy of Alexius Comnenus at Calavrytae, 1078, ByzS 6, 1979, p. 202-208; L. Neville, Heroes..., p. 126-127. ${ }^{48}$ Michael Attaleiates, XXXIV, 6, p. 530; Bryennios, IV, 12-13, p. 277-279; Zonaras, XVIII, 19, 6, p. 721-722; Skylitzes Continuatus, p. 180; Michael Glycas, p. 616; Komnene, I, 6, 5-6, p. 25-26; S. Rajković, Porodica..., p. 85-87.

${ }^{49}$ Michael Attaleiates, XXXIV, 7, p. 530-532; Zonaras, XVIII, 19, 6, p. 721-722; Skylitzes Continuatus, p. 180; Michael Glycas, p. 616; Komnene, I, 6, 9, p. 27; Bryennios, IV, 17, p. 283. 
later returned the property he took from him, and also gave him more ${ }^{50}$. Nikephoros Bryennios the Elder later became associated with the court of Alexios I Komnenos, and when he became emperor, he proved that by defending Adrianople against a usurper claiming to be the son of his adoptive brother, Roman Diogenes, in $1095^{51}$.

The third of our heroes, Nikephoros Bryennios the Younger, was born in Adrianople, best-educated among all his family members, and usually associated with a historical work probably written partly or entirely by him ${ }^{52}$. However, we are not completely sure if he was the son or grandson of his predecessor ${ }^{53}$. John Zonaras describes him with this first term, while Anna Komnena depicts him as the grandson of an earlier usurper ${ }^{54}$. His marriage to Anna was concluded in 1097, when Alexios I Komnenos raised him to the rank of panhypersebastos ${ }^{55}$. In the same year Nikephoros Bryennios (III) headed the troops mounted on the walls of Constantinople to discourage an attack on the city to be carried out by crusaders marching into the Holy Land ${ }^{56}$. These actions were successful. Bryennios spent the following years surrounded by his father-in-law, performing important tasks for him in internal politics, as well as taking part in his wars ${ }^{57}$. Anna Komnena recalls that at the end of Alexios's life, around 1115, as attempts were made at converting the Manichaeans from the city of Philippopolis, her father used Bryennios's (III) knowledge in the matter of holy books ${ }^{58}$. Alexios also benefited from his help during the battles with Selquks and their ruler Melikshah, the sul$\tan$ of Rûm ${ }^{59}$.

\footnotetext{
${ }^{50}$ Bryennios, IV, 18, p. 285; Skylitzes Continuatus, p. 184.24-25.

${ }^{51}$ Komnene, X, 3, p. 288-289; B. Skoulatos, Les personnages..., p. 223; S. Rajković, Porodica..., p. $90-91$.

${ }^{52}$ On the subject of authorship of this historical work and the controversy over whether Nikephoros was its author or someone else wrote it, see V. Stanković, Uvod..., p. 140-141; IDEM, Komnini..., p. $48,193$.

${ }^{53}$ However, S. Wittek-de Jong recognized him as a grandson of the rebel from 1078, and modern science has followed this point of view. S. WitTeK-DE Jong, Le césar Nicéphore..., p. 468.

${ }^{54}$ Zonaras, XVIII, 22, 23, p. 738; Komnene, VII, 1, 6, p. 206.

${ }^{55}$ Zonaras, XVIII, 22, 23-24, p. 738; B. Skoulatos, Les personnages..., p. 225; S. Rajković, Porodica..., p. 100.

${ }^{56}$ Komnene, X, 9, 6-10, p. 311-313; B. Skoulatos, Les personnages..., p. 225; W. Treadgold, The Middle..., p. 345; L. Neville, Heroes..., p. 16.

${ }^{57}$ Komnene, XII, 7, 4, p. 377-378; XIII, 7, 1, p. 403; XIII, 9, 2, p. 413; Actes d'Iviron, vol. II, Du milieu du XI siècle à 1204, ed. J. Lefort, N. Oikonomidès, D. Papachryssanthou, H. Métrévéli, V. Kravari, Paris 1990 [= AAth, 16], p. 230-231; B. Skoulatos, Les personnages..., p. 226-227; W. Treadgold, The Middle..., p. 345.

${ }^{58}$ Komnene, XIV, 8, 9, p. 457; S. Rajković, Porodica..., p. 105.

${ }^{59}$ Komnene, XV, 4-5, p. 472-476; B. Skoulatos, Les personnages..., p. 227; W. Treadgold, The Middle..., p. 346; S. Rajković, Porodica..., p. 106.
} 
Bryennios had a good relation with the father of his wife - Alexios I Komnenos, as well as with his mother-in-law - Eirena - who came from the Doukas family ${ }^{60}$. Reluctant to her son John, she favored Bryennios and Anna as the potential successors of her husband ${ }^{61}$. This is well confirmed by the words of Glykas and John Zonaras, who mention that thanks to Eirene Nikephoros had power in the palace, and even advocated judgments on behalf of his father-in-law ${ }^{62}$. This behavior of the mother did not escape the attention of John Komnenos, her son and his father's planned successor, who began to fear for his life and heritage ${ }^{63}$. As a result of this progressive conflict, two factions were born that wanted to have ultimate influence on who would become the new emperor. And when in 1118 Alexios I Komnenos became ill, his wife decided to act. Eirene, in conversations with her husband, began to praise the advantages of the character of kaisar Bryennios, as well as slandered her son, John ${ }^{64}$. As Nicetas Choniates reports to us, Alexios was aware of Eirena's love for Anna and her husband. So he ignored her suggestions, until he informed her that he would not pass his throne to a Macedonian (Bryennios) at the expense of his son ${ }^{65}$. John used his father's support and later became emperor himself. Upon hearing this, Eirene tried to encourage his son-in-law Bryennios to take the throne and to act against his wife's brother. Also, she promised her help in carrying out that plan but he did not take any action ${ }^{66}$. Another attempt was made by Eirene to force the dying Alexios to change the decision on the succession but it also failed ${ }^{67}$. The death of Alexios did not diminish the ambition of the mother and daughter, in which Nikephoros Bryennios the Younger was to be once again maneuvered.

\footnotetext{
${ }^{60}$ This relationship is particularly evident in the pages of a historical work related to Bryennios, where the author tried to present almost in a panegyric tone the right of the Dukas family to the imperial crown, in correlation with the Komnenian family. V. STANKović, Uvod..., p. 141-142.

${ }^{61}$ P. Magdalino, The Empire of Manuel I Komnenos, 1143-1180, Cambridge 1993, p. 193; V. StanKović, John II Komnenos before the Year 1118, [in:] John II Komnenos, Emperor of Byzantium. In the Shadow of Father and Son, ed. A. Bucossi, A.R. Suarez, London 2012, p. 18; V. STANKović, Komnini..., p. 90-106, 229-230.

${ }^{62}$ Michael Glycas, p. 622; Zonaras, XVIII, 26, 14-15, p. 754; B. Skoulatos, Les personnages..., p. 228; L. Neville, Heroes..., p. 18.

${ }^{63}$ Zonaras, XVIII, 24, 19, p. 748.

${ }^{64}$ Nicetae Choniatae Historia, ed. J.-L. van Dieten, Berlin-New York 1979 [= CFHB.SBe, 11] (cetera: Nicetas Choniates), p. 5, 1-5; W. Treadgold, The Middle..., p. 346; L. Neville, Heroes..., p. 19-20.

${ }^{65}$ Nicetas Choniates, p. 6, 20-24; B. Skoulatos, Les personnages..., p. 232; S. Rajković, Porodica..., p. 107.

${ }^{66}$ Nicetas Choniates, p. 7, 47-49.

${ }^{67}$ Nicetas Choniates, p. 7. Leonora Neville interprets these actions as an attempt to restore imperial power to the family of Doukas and Bryennios, at the same time, she suggests that the concept of the work of Nikephoros Bryennios the Younger arose before 1118, i.e. before the unsuccessful usurpation of Eirene and Anna. L. Neville, A History..., p. 169; EAdem, Heroes..., p. 28.
} 
A different version of these events is provided by an anonymous chronicle from Eddesa, whose author suggests that the plot was attempted by Nikephoros Bryennios and his mother-in-law Eirene, who were hostile to John II. The latter, anticipating the actions of the conspirators, was able to attack the imperial palace which he captured along with the treasury, while his brother-in-law was sent into exile, and his mother was locked up in a monastery ${ }^{68}$. There is no question of Anna Komnena's activity and her influence on her husband's actions. The existence of this source account confirms that Eirene's actions against her birth son were also followed by elites from the borderlands of the Byzantine Empire, which is why the account of that event has survived in this form, different from other sources.

In 1119, when John II Komnenos camped close to Philiopation, near the capital, a conspiracy was established to physically eliminate the emperor. Anna Komnena attempted to usurp the imperial power by gathering her supporters around her husband. They managed to bribe the guards of the city gates, but Bryennios again broke the whole action and showed no enthusiasm for the plans of his wife and her supporters. The attack failed because the potential usurper did not join it ${ }^{69}$. This caused Anna's anger and during an intercourse with Bryennios she caused a painful contraction of her vagina to punish him ${ }^{70}$. Mentioning this event, Choniates constructed his narrative in such a way as to show from his time perspective (the beginning of the $13^{\text {th }}$ century) the beginning of the fall of the Komnenian family, and to greatly diminish Anna's role and significance ${ }^{71}$. The next day, at the news of the conspiracy, John punished the people taking part in it, including his sister, with the loss of their property ${ }^{72}$. The fact that Byzantine sources do not mention any punishment for Nikephoros Bryennios the Younger, but only for his wife, shows that John II was perfectly aware of who was the main initiator of the attempted assassination. Until his death in 1137, Nikephoros Bryennios the Younger remained near John $\mathrm{II}^{73}$.

Each of the revolts related to the Bryennios family presented above was different and resulted from different reasons. The first one ended before it could begin. This was due to the excessive confidence of Nikephoros the ethnarch who underestimated the ability and fitness of those faithful to the ruling emperor, for which he was punished with blindness. The second Nikephoros Bryennios operated in different conditions and was the first man from his family to usurp the imperial power. He had the perfect opportunity for this in the era of chaos that swept

\footnotetext{
${ }^{68}$ Anonymi auctoris Chronicon ad annum Christi 1234 pertinens, vol. II, ed. J.B. Снавот, Paris 1916 [= CSCO.SS, Ser. 3, 15], p. 63; L. Neville, Heroes..., p. 23.

${ }^{69}$ Nicetas Choniates, p. 10; B. Skoulatos, Les personnages..., p. 228, 230; W. Treadgold, The Middle..., p. 346; S. Rajković, Porodica..., p. 108-109.

${ }^{70}$ Nicetas Choniates, p. 10, 52-56.

${ }^{71}$ L. Neville, Heroes..., p. 23-24.

${ }^{72}$ Nicetas Choniates, p. 11-12.

${ }^{73}$ Komnene, I, 3, 4, p. 8; B. Skoulatos, Les personnages..., p. 228-229.
} 
Byzantium during the reign of the last of the Doukas. Unfortunately, having facilities in the Balkans, Thrace and Macedonia did not determine his success in the first phase of his usurpation. The problems of Bryennios helped another competitor to the imperial crown to capture the capital of the empire. Lost battles and an inept attempt to seize Constantinople worked against our hero. Alexios Komnenos dealt the last blow to his plans, defeating him in the battle of Kalavrye.

Probably it was the failure of this usurper that influenced the attitude of his family towards a new dynasty. Alexios bonding the Bryennios household with the Komnenian family through the marriage with Anna to some extent satisfied their ambitions. He gained powerful and influential allies in Macedonia and Thrace, who remained faithful to him in the later years of his reign. Nikephoros Bryennios the Younger, being constantly surrounded by Alexios, had feelings for him similar to those he had for his real father and grandfather. In the introduction to his historical work Bryennios strongly emphasizes that usurpation against the ruling emperor, who is predestined for imperial power, is one of the most serious offenses that a man can commit ${ }^{74}$. Bryennios (III) treated Alexios as a kind of messiah, a savior who tried to rebuild the lands of the Romans and raise them from the fall. Nikephoros Bryennios the Younger was a faithful man and put fidelity above all else, so he became one of the people of Komnenian clan, with direct access to the emperor ${ }^{75}$. Alexios was also a model for Bryennios (III) on how to deal with women. Warren Treadgold rightly describes Bryennios's attitude towards his wife as the same as that of Alexios towards his wife Eirene, namely passive resistance to her demands ${ }^{76}$.

Philiopation, the place where Anna Komnene planned to overthrow her brother John II, also had a significance for Nikephoros Bryennios the Younger, which his wife seems to have forgotten. It was there that in 1078 his grandfather was blinded by the people of Nikephoros III ${ }^{77}$. Having among his predecessors two blind men who challenged the authority of the emperors and lost, Bryennios (III) probably did not want to join them. He therefore chose to be faithful to the idea of the Komnenian family at the expense of his own, which he founded with Anna. He was not the soldier type but more of a philosopher and scientist, or an idealist ${ }^{78}$. Of course, our basic sources of information about the last of the Bryennios are very subjective, especially Anna Komnena and Choniates, so it is hard to believe their full description of the character of Nikephoros Bryennios. Anna idealized her husband, and at the same time diminished the role of her brother John, while

\footnotetext{
${ }^{74}$ Bryennios, Preface, 10, p. 69-71.

${ }^{75} \mathrm{He}$ reveals these views in a fragment of his work in which he describes the transition of Alexios Komnenos to the side of the usurper Botaniates. BRYennios, III, 23, p. 251.

${ }^{76}$ W. Treadgold, The Middle..., p. 346.

${ }^{77}$ Bryennios, IV, 17, p. 283.

${ }^{78}$ P. Magdalino, The Empire..., p. 194.
} 
Choniates knew the story of Bryennios from the descriptions of other Byzantines. The personality and some events from the life of Bryennios (III) are also described by Theodoros Prodromos in his prose and poetry where he mentions the wisdom of kaisar, his greatness as a man, the double wedding of his sons, and finally his death after Alexios and Eirene ${ }^{79}$. Theodoros Prodromos also dedicated one of his works to him, entitled: To Kaisar, or about green. Green refers to the ceremonial color of the cloths assigned to the rank of kaisar, worn by Bryennios (III), which is better to Prodromos than blue and white ${ }^{80}$. We can look for a hidden dimension in the poet's words about colors because he personally knew the last of our heroes and the matter of his possible participation in the plot against John II or his absence would have to be known to him. The praise of green can therefore be read as the praise of the attitude of the kaisar who preferred to stick to the color given to him by his father-in-law rather than reach for the imperial purple. Victory at all cost, including the killing of his kinsmen, as Leonor Neville rightly pointed out, was not for him, and was not the road he would decide to take ${ }^{81}$.

\section{Bibliography}

\section{Primary Sources}

Actes d'Iviron, vol. II, Du milieu du XI siècle à 1204, ed. J. LeFort, N. Oikonomidès, D. PAPAChrysSanthou, H. Métrévéli, V. Kravari, Paris 1990 [= Archives de l’Athos, 16].

Annae Comnenae Alexias, vol. I, rec. D.R. Reinsch, A. Kambylis, Berlin 2001 [= Corpus fontium historiae byzantinae. Series Berolinensis, 40].

Anonymi auctoris Chronicon ad annum Christi 1234 pertinens, vol. II, ed. J.B. Снавот, Paris 1916 [= Corpus scriptorum christianorum orientalium. Scriptores Syri, Ser. 3, 15].

Constantine Porphyrogenitus, De administrando imperio, ed. G. Moravcsik, trans. R.J.H. JenKINs, Washington 1993 [= Corpus fontium historiae byzantinae, 1; Dumbarton Oaks Texts, 1].

$\bar{E}$ synecheia tēs Chronographias tou Iōannou Skylitzēe. (Ioannes Skylitzes Continuatus), ed. E.T. TsoLAKĒs, Thessalonikē 1968.

Ioannis Scylitzae Synopsis historiarum, rec. I. THuRn, Berolini 1973 [= Corpus fontium historiae byzantinae, 5].

Ioannis Zonarae Epitome historiarum libri XIII-XVIII, rec. T. BüTTNER-WoBst, Bonnae 1897 [= Corpus scriptorum historiae byzantinae, 49].

\footnotetext{
79 Theodoros Prodromos, Historische Gedichte, ed. W. Hörandner, Wien 1974 [= WBS, 11] (cetera: Theodoros Prodromos), II, 41, p. 186, 96, p. 188; XXXIX, 171, p. 387; Theodore Prodromos, Rhodanthe and Dosikles, I, 1-4, [in:] Four Byzantine Novels, trans. E. JefFreys, Liverpool 2012 [= TTB, 1], p. 19.

${ }^{80}$ Theodoros Prodromos, p. 51.

${ }^{81}$ L. Neville, Heroes..., p. 180-181.
} 
Michael Attaleiates, The History, ed. A. Kaldellis, D. Krallis, Cambridge Mass. 2012 [= Dumbarton Oaks Medieval Library].

Michaelis Glycae Annales, rec. I. BEKKER, Bonnae 1836 [= Corpus scriptorum historiae byzantinae, 24].

NicÉPhore Bryennios, Histoire, rec. P. Gautier, Bruxelles 1975 [= Corpus fontium historiae byzantinae, 9].

Nicetae Choniatae Historia, ed. J.-L. van Dieten, Berlin-New York 1979 [= Corpus fontium historiae byzantinae. Series Berolinensis, 11].

Theodoros Prodromos, Historische Gedichte, ed. W. Hörandner, Wien 1974 [= Wiener byzantinistische Studien, 11].

Theodore Prodromos, Rhodanthe and Dosikles, [in:] Four Byzantine Novels, trans. E. Jeffreys, Liverpool 2012 [= Translated Texts for Byzantinists, 1].

\section{Secondary Literature}

Birkenmeier J., The Development of the Komnenian Army, 1081-1180, Leiden 2002.

Bonarek J., Bizancjum $w$ dobie bitwy pod Mantzikert. Znaczenie zagrożenia seldżuckiego w polityce bizantyńskiej w XI wieku, Kraków 2011 [= Notos. Scripta Antiqua et Byzantina, 7].

Bӧнм M., The Military Policy of Isaac Komnenos at the Time of Battle of Petroe (1057), "Open Political Science" 1, 2018, p. 136-142, https://doi.org/10.1515/openps-2018-0011

Curta F., The Edinburgh History of the Greeks, c. 500 to 1050. The Early Middle Ages, Edinburgh 2011, https://doi.org/10.3366/edinburgh/9780748638093.001.0001

De Vries-Van Der Velden E., Psellos, Romain IV Diogenes et Mantzikert, "Byzantinoslavica. Revue internationale des études byzantines" 58, 1997, p. 274-310.

Dudek J., Pęknięte zwierciadło. Kryzys i odbudowa wizerunku władcy bizantyńskiego od 1056 do ok. 1095 roku, Zielona Góra 2009.

Haldon J., The Byzantine Wars. Battles and Campaigns of the Byzantine Era, Stroud 2001.

Howard-Johnston J., Anna Komnene and the Alexiad, [in:] Alexios I Komnenos, ed. M. Mullett, D. Sмyтне, Belfast 1996, p. 232-302.

Inoue K., The Rebellion of Isaakios Komnenos and the Provincial Aristocratic Oikoi, "Byzantinoslavica. Revue internationale des études byzantines" 54, 1993, p. 268-278.

Jeffreys E., Nikephoros Bryennios Reconsidered, [in:] The Empire in Crisis(?). Byzantium in the $11^{\text {th }}$ Century, (1025-1081), ed. V.N. Vlyssidou, Athens 2003, p. 211-213.

Kazhdan A., Bryennios, [in:] The Oxford Dictionary of Byzantium, vol. I, ed. A. Kazhdan et al., New York-Oxford 1991, p. 328-329.

Kazhdan A., Bryennios, Nikephoros the Younger, [in:] The Oxford Dictionary of Byzantium, vol. I, ed. A. Kazhdan et al., New York-Oxford 1991, p. 331.

KrsmanoviĆ B., Uspon vojnog plemstva u Vizantii XI veka, Beograd 2001.

Macrides R., The Pen and the Sword: Who Wrote the Alexiad?, [in:] Anna Komnene and Her Times, ed. T. Gouma-Peterson, New York 2000, p. 63-81, https://doi.org/10.4324/9780203765234-4

Magdalino P., The Empire of Manuel I Komnenos, 1143-1180, Cambridge 1993, https://doi.org/10. $1017 / \mathrm{CBO} 9780511523182$

Neville L., Heroes and Romans in Twelfth-Century Byzantium. The Material for History of Nikephoros Bryennios, Cambridge-New York 2012, https://doi.org/10.1017/CBO9780511933967 
Neville L., A History of the Caesar John Doukas in Nikephoros Bryennios' Material for History?, "Byzantine and Modern Greek Studies” 32, 2008, p. 168-188, https://doi.org/10.1179/174962508X322669

Paroń A., Pieczyngowie. Koczownicy w krajobrazie politycznym i kulturowym średniowiecznej Europy, Wrocław 2015.

Rajković S., Porodica Vrijenija u XI i XII stoleću, Belgrade 2003.

Reinsch D.R., O Nikēphoros Bryennios - enas "Makedonas" synnrapheas, [in:] V Diethnes Symposio Byzantinē Makedonia. Dikaio, theologia, philologia, Thessalonikē 2003, p. 169-177.

SEgER J., Byzantinische Historiker des zehnten und elften Jahrhunderts, vol. I, Nikephoros Bryennios, München 1888.

Skoulatos B., Les personnages byzantins de l'Alexiade. Analyse prosopographique et synthèse, Louvain-la-Neuve 1980.

Stanković V., John II Komnenos before the Year 1118, [in:] John II Komnenos, Emperor of Byzantium. In the Shadow of Father and Son, ed. A. Bucossi, A.R. SuArez, London 2012, p. 11-21.

Stanković V., Komnini u Carigradu (1057-1185). Evolucija jedne vladarske porodice, Belgrade 2006.

Stanković V., Nikephoros Bryennios, Anna Komnene and Konstantios Doukas. A Story about Different Perspectives, "Byzantinische Zeitschrift" 100, 2007, p. 169-175, https://doi.org/10.1515/ BYZS.2007.169

Stanković V., Uvod u Materijal Istorije Nićifora Vrijenija, “Зборник Радова Византолошког Института" / "Zbornik Radova Vizantološkog Instituta” 47, 2010, p. 137-148, https://doi.org/ 10.2298/ZRVI1047137S

Stephenson P., Byzantium's Balkan Frontier. A Political Study of the Northern Balkans, 900-1204, Cambridge 2000, https://doi.org/10.1017/CBO9780511496615

Theoktistos Bryennios, [in:] Prosopographie der mittelbyzantinischen Zeit, Abt. I, (641-867), vol. IV, Platon - Theophylaktos, ed. F. Winkelmann, R.-J. Lilie, Berlin 2001, p. 581-582, no. 8052.

Tobias N., The Tactics and Strategy of Alexius Comnenus at Calavrytae, 1078, "Byzantine Studies/ Études byzantines" 6, 1979, p. 193-211.

Treadgold W., The Middle Byzantine Historians, Basingstoke 2013, https://doi.org/10.1057/ 9781137280862

Wittek-De Jong S., Le césar Nicéphore Bryennios, l'historien, et ses ascendantes, "Byzantion. Revue internationale des études byzantines" 23,1953, p. 463-468.

\footnotetext{
Abstract. Nikephoros Bryennios the Younger has a place in the history of Byzantium as the author of one of the works devoted to the Komnenos family coming to power. This outstanding observer and talented leader, who was fascinated by the person of his father-in-law Alexius I Komnenos, came from a family whose ambitions were no less than the those in the one into which Nikephoros himself married. His father and grandfather, also his namesake, were those who dreamed of an imperial crown for themselves and tried to reach for it armed. Apart from defeat, they both faced punishment which was blinding. One of those who captured and ordered the father of Nikephoros the Younger to be blinded was his future father-in-law. Like the later marriage with Anna Komnene, this had an impact on the respect he had for the new dynasty. However, the question is whether this respect should be explained by the man's reluctance to participate in a plot against his brother-in-law that his ambitious wife and her mother planned.
} 
Keywords: Nikephoros Bryennios the Younger, Anna Komnene, Komnenian clan, Byzantine Empire, Balkans

Marcin Böhm

University of Opole

Faculty of Social Studies

Institute of History

ul. Strzelców Bytomskich 2

45-084 Opole, Polska/Poland

mabohm@wp.pl 